\title{
Fellesnevner, men ulikt opphav
}

Pulmonal hypertensjon er en kompleks og multidisiplinær sykdom, der klassifisering og retningslinjer for diagnostikk og behandling ble revidert i $2009(1,2)$. Middeltrykket $i$ arteria pulmonalis er per definisjon $\geq 25$ $\mathrm{mm} \mathrm{Hg}$ i hvile bedømt med høyresidig hjertekateterisering. Ved prekapillær form for pulmonal hypertensjon (gruppe $1,3,4$, og 5 ) er innkilt lungearterietrykk $\leq 15 \mathrm{~mm} \mathrm{Hg}$ og reflekterer normale trykk i venstre atrium. Dette er i motsetning til postkapillær pulmonal hypertensjon med $>15 \mathrm{~mm} \mathrm{Hg}$ (gruppe 2), som uttrykk for økt fylningstrykk på venstre side av hjertet. Inndelingen i fem grupper er basert på patologiske, patofysiologiske og terapeutiske karakteristika:

Gruppe 1, Pulmonal arteriell hypertensjon $(P A H)$, er en sykdom som rammer de små lungearteriene, først i form av vasokonstriksjon og senere med remodellering og strukturelle forandringer som øker pulmonal vaskulær motstand. Små kar obstrueres etter hvert, og høyre ventrikkel møter en motstand som over tid utløser sviktende funksjon og fallende minuttvolum. Ubehandlet er prognosen svært dårlig, og selv om nyere medikamenter (endotelinreseptorblokkere, fosfodiesterase type-5-inhibitorer og prostanoider) har bedret leveutsiktene, finnes det ingen kurativ behandling (3). I tillegg til en idiopatisk form finnes former assosiert med bl.a. bindevevssykdom, leversvikt, hiv og medfødte hjertefeil.

Gruppe 2, Pulmonal hypertensjon ved venstresidig hjertesykdom, oppstår sekundært til sviktende systolisk eller diastolisk funksjon av venstre ventrikkel og ved klaffefeil. Økt fylningstrykk på venstre side vil over tid forplante seg til lungekretsløpet med venøs trykkøkning, som igjen kan forplante seg til kapillærene og den arterielle siden. Medikamenter spesifikke for pulmonal arteriell hypertensjon er kontraindisert ved venstresidig hjertesvikt og kan forverre pasientenes leveutsikter $(1,2)$.
Gruppe 3, Pulmonal hypertensjon ved lungesykdommer, synes også å ha en sammensatt bakgrunn, men er primært betinget $\mathrm{i}$ kronisk hypoksemi (4). Denne gruppen er oftest preget av lavere trykk og mindre hemodynamiske forstyrrelser enn i de to forrige gruppene, også ved avansert sykdom. Tiltak utover kronisk oksygenbehandling på nesekateter er uten dokumentasjon (4).

Gruppe 4, Pulmonal hypertensjon ved kronisk tromboembolisme, er en potensielt kurabel sykdom ved trombendarterektomi. Medikamenter spesifikke for pulmonal arteriell hypertensjon har ikke vist sikre gunstige effekter i randomiserte studier (5), og for dem som ikke er kandidater for kirurgi eksisterer per i dag intet dokumentert behandlingstilbud $(1,2)$.

Gruppe 5, Pulmonal hypertensjon ved uklare og/eller multifaktorielle mekanismer. Pulmonal tumor trombotisk mikroangiopati, som den aktuelle pasienten hadde, er klassifisert her, sammen med hematologiske tilstander som splenektomi, systemiske sykdommer som sarkoidose og metabolske forstyrrelser som Gauchers sykdom. Denne gruppen er en «samlesekk» betinget i sjeldne sykdommer og med manglende konsensus om behandling. Kasuistikken angir de mange diagnostiske hjelpemidlene og differensialdiagnostiske overveielsene under utredning, og det argumenteres overbevisende for tverrfaglig samarbeid. Vi får beskrevet skjebnen som rammer mange pasienter i alle de fem gruppene, også til tross for behandling, med progredierende høyresidig hjertesvikt og død. Fra kardiologisk side kunne høyresidig hjertekateterisering (med aspirasjon av tumorceller i innkilt lungearterieposisjon), i tillegg til ekkokardiografi, gitt en ante mortem diagnose. Mens en sikker diagnose ellers er avgjørende for korrekt behandling, ville den i dette tilfellet vært av usikker verdi.

\section{Arne K. Andreassen}

arne.andreassen@rikshospitalet.no

Kardiologisk avdeling

Oslo universitetssykehus, Rikshospitalet

Arne K. Andreassen (f. 1956) er spesialist i kardiologi og leder program innen hjertesvikt/ hjertetransplantasjon og innen pulmonal hypertensjon ved Kardiologisk avdeling, Oslo universitetssykehus, Rikshospitalet. Ingen oppgitte interessekonflikter.

\section{Litteratur}

1. McLaughlin W, Archer SL, Badesch DB et al. ACCF/AHA 2009 expert consensus document on pulmonary hypertension a report of the American College of Cardiology Foundation Task Force on Expert Consensus Documents and the American Heart Association developed in collaboration with the American College of Chest Physicians; American Thoracic Society, Inc.; and the Pulmonary Hypertension Association. J Am Coll Cardiol 2009; 53: $1573-619$

2. Galiè N, Hoeper MM, Humbert M et al. Guidelines for the diagnosis and treatment of pulmonary hypertension. The Task Force for the Diagnosis and Treatment of Pulmonary Hypertension of the European Society of Cardiology (ESC) and the European Respiratory Society (ERC), endorsed by the International Society of Heart and Lung Transplantation (ISHLT). Eur Respir J 2009: 30 : 2493-537.

3. Andreassen AK, Gude E, Solberg OG et al. Behandling av idiopatisk pulmonal arteriell hypertensjon. Tidsskr Nor Legeforen 2011: 131: 1285-8.

4. Wrobel JP. Thompson BR, Williams TJ. Mechanisms of pulmonary hypertension in chronic obstructive pulmonary disease: A pathophysiologic review. J Heart Lung Transplant 2012; 31: 557-64.

5. Jaïs X, D'Armini AM, Jansa P et al. Bosentan for treatment of inoperable chronic thromboembolic pulmonary hypertension: BENEFiT (Bosentan Effects in iNopErable Forms of chronlc Thromboembolic pulmonary hypertensionl, a randomized placebo-controlled trial. J Am Coll Cardiol 2008; 52: 2127-34

Mottatt 20.6.2012 og godkjent 26.6. 2012. Medisinsk redaktør Siri Lunde. 